\title{
BRIC AGRICULTURAL POLICIES THROUGH A WTO LENS
}

\section{Lars Brink, David Orden, and Giselle Datz}

T

his chapter examines agricultural policies of the BRIC (Brazil, the Russian Federation, India, China) through the prism of the disciplines on domestic support under the Agreement on Agriculture (AoA) of the World Trade Organization (WTO). ${ }^{1}$ The effects of agricultural policies of the BRIC on production and trade have implications for their own domestic (and also global) food security as well as for world agricultural markets. As the BRIC have emerged as global economic powers, and their per capita incomes rise, questions intensify in a historical context about their governments' future treatment of agriculture. We examine the obligations in the WTO of the BIC (Brazil and India, members since 1995, and China, which acceded in 2001) and how they have notified their agricultural support to demonstrate compliance with the rules and their commitments. The inclusion of the Russian Federation under the WTO disciplines in 2012 demonstrates the disciplines' relevance even in the absence of a new agreement, and we discuss the disciplines on agricultural support established for the Russian Federation in its accession. We also assess the new rules that were negotiated in the Doha Round before it faltered at the end of 2008 as they would apply to the BRIC. While the prospect for adoption of new Doha disciplines has become remote, the negotiated provisions are informative about the future policy space the BRIC and other countries sought to maintain.

Until the Uruguay Round, it had proved impossible to achieve multilateral disciplines on the protection of and support for agriculture. The 1994 Agreement on Agriculture set forth the first such rules with the objective over time of achieving substantial and progressive reductions in distortions to

1 This chapter was originally published as an article in the Journal of Agricultural Economics 64, no. 1 (February 2013): 197-216. The authors have benefited from the earlier work of Fuzhi Cheng (2011), Munisamy Gopinath (2011, 2012), and André Nassar (2011) and from comments of the participants in the 2011 Leibniz Institute of Agricultural Development in Transition Economies (IAMO) forum titled "Will the 'BRICs Decade' Continue?-Prospects for Trade and Growth." 
world markets. Eighteen years of experience have subsequently demonstrated how difficult this task remains. In the area of agricultural domestic support, countries have largely shown compliance with their legal obligations, and their WTO notifications track various changes in policies and expenditures. However, difficulties arise over whether the notifications to the WTO provide timely, accurate, and meaningful measurement of economic support and whether the disciplines have contributed to reducing trade distortions.

These analytical issues arise in evaluating the agricultural policies of the BRIC through the WTO lens. The situation of agriculture within their economies differs, leading to differences in their policy initiatives and an absence of a coordinated international stance. In addition, the details of the WTO rules apply differently to each one of the BRIC countries. The differences in the provisions applying to the four BRIC derive from a combination of several underlying differences. One is the difference in the rules for developing and developed countries. Special and differential treatment for developing countries is a principle in the WTO framework. However, developing-country status essentially results from self-declaration and has over time become less associated with economic criteria. Several members of the OECD (Organisation for Economic Co-operation and Development) use the developing-country provisions of the WTO Agreement on Agriculture (Chile, Israel, Mexico, South Korea [Republic of Korea], and Turkey). As developing countries in the WTO, Brazil, India, and China enjoy certain flexibilities on the level and type of agricultural support that is subject to WTO limits. The Russian Federation, as a developed country, does not enjoy the same flexibilities.

Another difference relates to the level and type of the support the BRIC provided in earlier years, which form the base for their WTO ceiling commitments on support. This gives Brazil and the Russian Federation latitude for a certain amount of subsidies within their ceiling commitments-they have a Bound Total Aggregate Measurement of Support (Bound Total AMS) greater than nil. ${ }^{2}$ India and China do not have that particular latitude-their Bound Total AMS is nil. A third difference results from the processes used to establish the rules and commitments of the BRIC: negotiations in the Uruguay Round for Brazil and India, negotiations on WTO accession for the Russian Federation and China. For example, under a rule negotiated in China's accession, which deviated from earlier practice in developing-country accessions, China cannot exempt certain input subsides from WTO disciplines. Also

2 Bound Total AMS is a ceiling commitment, above which WTO members are not authorized to allow their Current Total AMS (see further discussion below). 
under the 2008 Doha draft disciplines, the four BRIC would enjoy large but different degrees of flexibility to provide distorting support. The flexibilities would result from the particular Doha rules applying to developing countries (Brazil, India, and China) and to members that have acceded to the WTO after 1995 (the Russian Federation and China).

Thus, for the BRIC as a group, there is little substantial commonality of circumstance under the WTO disciplines on agricultural domestic support, except that the existing or possible future constraints allow considerable flexibility. Nevertheless, the WTO rules and their commitments will play some role in determining the extent and form of any distortionary policies the BRIC individually or collectively pursue as their incomes rise and they transform over the coming decades into economies in which agriculture accounts for a smaller share of national incomes.

\section{Agriculture in the BRIC Economies}

The levels of real GDP (gross domestic product) of the BRIC are shown for 1995-2010 in Figure 5.1a (constant 2000 US dollars). The rapid growth of China's economy relative to the others is evident as it more than tripled in size over 15 years. India also shows substantial growth, essentially doubling in size from a lower initial level. By comparison, Brazil and the Russian Federation show much slower growth. The 1995 per capita real GDP (not shown) was only US\$372 in India and US\$657 in China, compared to US\$1,618 in the Russian Federation and US $\$ 3,609$ in Brazil. By 2009, per capita GDP had risen to US\$766 in India and US\$2,206 in China, compared to US\$2,805 in the Russian Federation and US\$4,399 in Brazil. The per capita income comparisons go a long way toward explaining differences in levels of agricultural income (value-added) relative to total GDP among the BRIC. The percentage of GDP accounted for by agriculture was initially far higher in India and China than in the Russian Federation and Brazil (Figure 5.1b). The share of GDP accounted for by agriculture dropped sharply in China (by half) as its economy grew; likewise, agriculture's share of the Indian economy dropped by 30 percent as the economy doubled.

The economic importance of agriculture in Brazil is more evident in its international trade. Agriculture and food accounted for one-third of Brazil's merchandise exports throughout the 15 years, fluctuating with highs and lows of world prices and other factors (Figure 5.1c). In contrast, the Russian Federation's agriculture and food exports were only 5 percent of merchandise exports. Agriculture and food exports declined as a share of the total 
FIGURE 5.1 Growth and agriculture among the BRICs
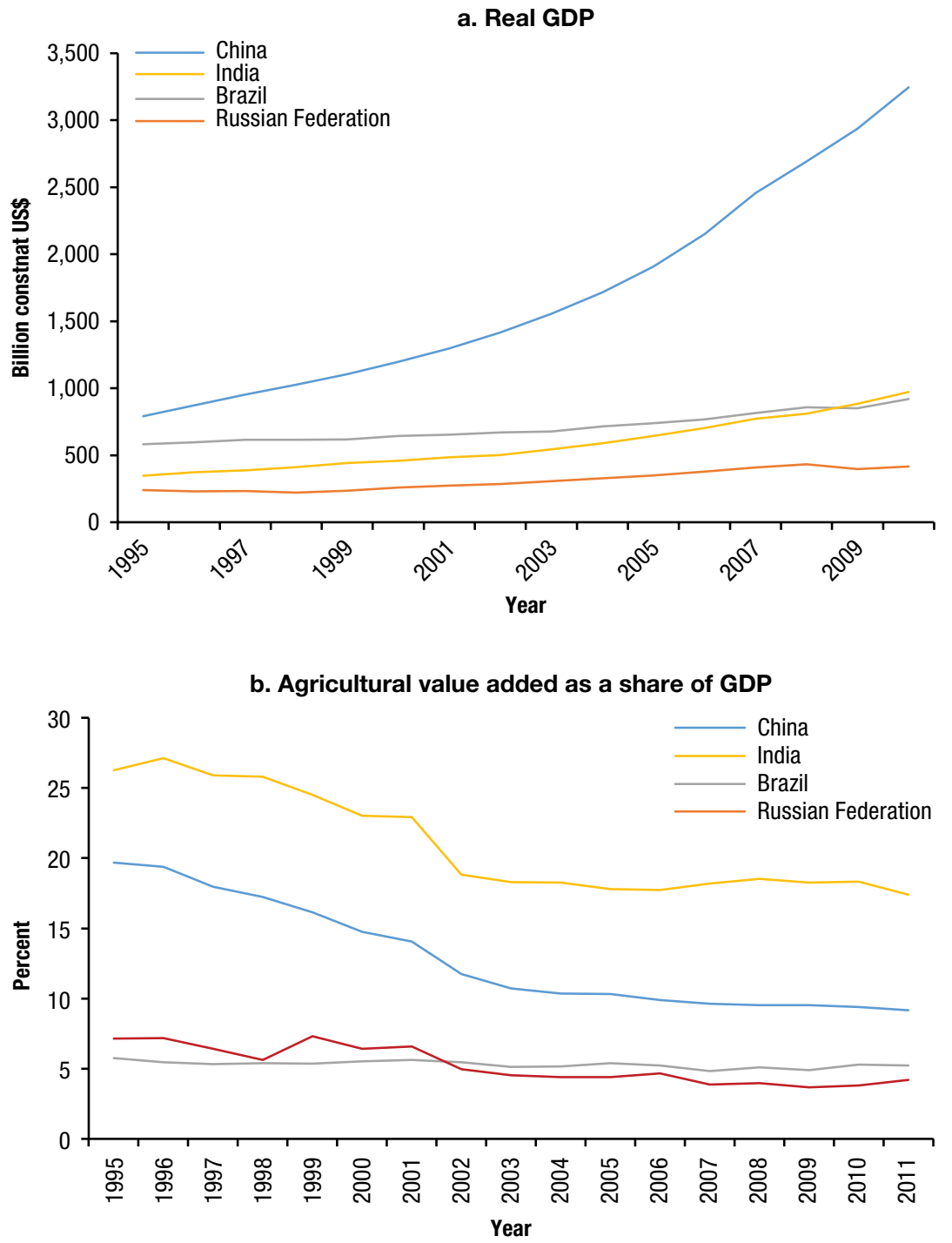

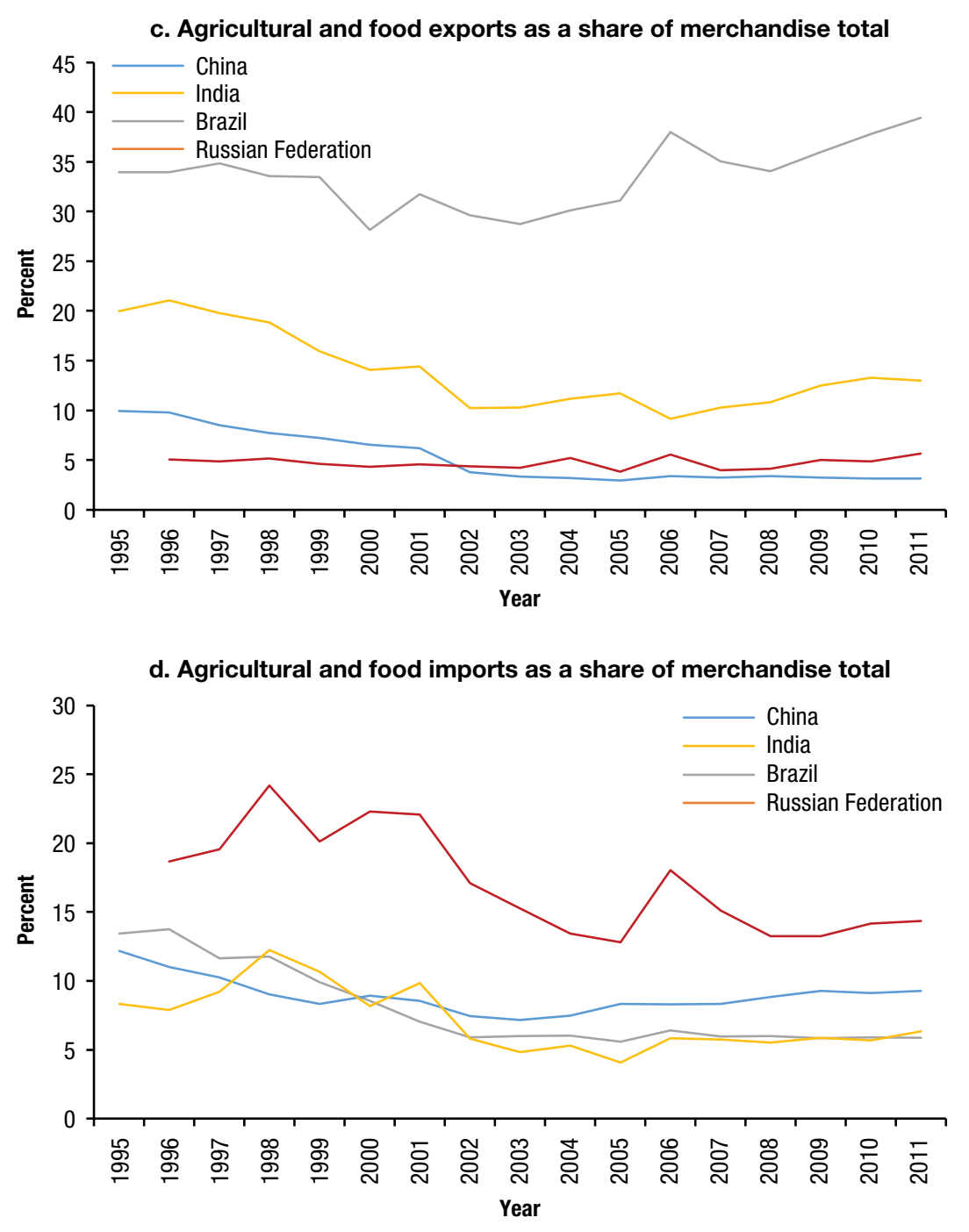

Source: Authors' calculations from IMF and World Bank data.

Note: BRICs = A group of emerging economies consisting of Brazil, the Russian Federation, India, and China.

exports of China and India and by 2010 were closer to the share in the Russian Federation than in Brazil. The share of agriculture and food in merchandise imports is higher for the Russian Federation than the other BRICs (Figure 5.1d). There is a downward trend in the share of merchandise imports accounted for by agriculture and food in all four countries, not just for China and India, where overall growth has been highest. 


\section{Participation in WTO Agricultural Governance}

Given the differences in their agriculture and agricultural trade, the BIC have played quite different roles in WTO governance processes for agriculture. Brazil has been forceful in using the WTO's dispute settlement process to discipline support for agriculture in developed countries. ${ }^{3}$ In US-Agriculture Subsidies, a case that is still pending but not actively under adjudication, Brazil contends (similar to a case first brought by Canada) that the United States violated its WTO support commitment in almost every year between 1999 and 2005. In US-Upland Cotton the WTO Appellate Body found under the Agreement on Subsidies and Countervailing Measures that numerous price-contingent US subsidies gave rise to serious prejudice to the interests of Brazil. In EC-Sugar, brought by Australia, Brazil, and Thailand, the Appellate Body expressed the view that domestic support was the source of the export subsidy that was found to exist. These cases demonstrate that a country can be challenged for violating the WTO rules because of the size and nature of its agricultural support. However, it has proven relatively easy for countries to meet their commitments under the domestic support disciplines of the WTO's Agreement on Agriculture.

Like many other countries, the BIC have notified their agricultural domestic support to the WTO Committee on Agriculture only with substantial delays, and notifications for recent years are still outstanding. The delays may in some situations, for the BIC as for other countries, be explained by difficulties in gathering the necessary data in a timely fashion, resulting from, for example, inadequate data collection procedures or allocation of too few resources to the task. However, the absence of a country's notifications for many years is more difficult to explain. Some countries may perceive gaining a strategic advantage from not revealing details on their farm support in the WTO notification format, whether for the regular work of the Committee on Agriculture or for the Doha negotiations initiated in 2001. The individual BIC countries have differed in their notification approaches (the Russian Federation's 2012 accession is too recent for delays in annual domestic support notification yet to have been incurred).

Brazil provided relatively prompt notifications in the early years of the WTO, but its notifications became delayed once the Doha Round began. No annual notifications were submitted by Brazil between 2000 and 2004,

3 Contentious issues are also addressed in bilateral negotiations and through the WTO Committee on Agriculture, as evidenced in the Committee's meeting reports. See Brink (2011) for elaboration on dispute settlement. 
followed by notifications of support through 2008-2009 in February 2012. China provided notification information for 1996-1998 in 2001 as it acceded to the WTO, provided additional notifications through 2001 in October 2006, but notified support through 2008 only in October 2011. A more extreme case of failing to submit timely notifications is India. As late as in May 2011, its notifications of domestic support covered only three years, 1995/1996-1997/1998. In June 2011 domestic support notifications from India were circulated, but only going as far as 2003-2004. Delays such as these mean that timely information was not available during the Doha negotiations and have made it difficult for the WTO Committee on Agriculture to carry out its mandate to review the implementation of commitments. In contrast, regular up-to-date reviews of agricultural policies and support are prepared by the OECD but only for its limited membership and certain emerging economies, including Brazil, the Russian Federation, and China but not India.

All three BIC countries are members of the G20 WTO negotiation group of developing countries that argued in the Doha negotiations for deep cuts to agricultural support in the developed countries (WTO 2011a). ${ }^{4}$ Brazil has been particularly forceful in pressing this case. On other agricultural issues, sharp differences have divided the BIC. India has sought rules for agricultural tariff safeguard mechanisms that Brazil has vigorously opposed. Cohesion among the BIC goes only so far-it prevails mainly when it comes to seeking concessions from developed countries, but not to initiatives that affect their diverse individual trade interests. It is unclear how the Russian Federation will seek to pursue its interests in the WTO and how its chosen approaches might affect the governance and accomplishments of the organization. Kerr (2012) espouses a pessimistic view, based on an assessment that the characteristics of the Russian Federation economy are antipathetic to WTO membership, including the idea that the Russian Federation would not be interested in an ambitious Doha outcome. This contrasts with the optimistic view that, based on the rule of trade law, the Russian Federation's membership will cement its integration into the global economy (Lamy 2011). The aims of each BRIC country concerning domestic support in the Doha Round would not be expected to differ from the usual apparent aims of other WTO members, which tend not to be driven by a purely economic rationale. Any BRIC country might thus want to preserve its

4 This G20 group in the WTO agricultural negotiations is distinct from the G20 group of major economies brought together regularly to address global economic issues. In 2012 the $23 \mathrm{mem}$ bers of the G20 in the WTO comprised Argentina, Bolivia, Brazil, Chile, China, Cuba, Ecuador, Egypt, Guatemala, India, Indonesia, Mexico, Nigeria, Pakistan, Paraguay, Peru, Philippines, South Africa, the United Republic of Tanzania, Thailand, Uruguay, Venezuela, and Zimbabwe. 
own entitlements to provide distorting support while also wanting to constrain such room in countries to which it exports, from which it imports, and with which it competes in third-country export markets. While it may be difficult to pursue domestic support interests on a product-by-product basis, the balance between the constraints on product-specific and non-product-specific support could be the subject of divergent priorities among BRIC countries.

\section{WTO Disciplines on BRIC Agricultural Support}

The WTO rules for domestic support are complicated (WTO 1995b). ${ }^{6}$ Those countries that provided significant levels of support in the 1986-1988 base period established a ceiling commitment (Bound Total AMS) on certain production-related support, such as budgetary outlays and support through administered prices. Such support was summed across all basic agricultural products and a non-product-specific category. Most developing countries had no or only low levels of support in 1986-1988 and consequently they have a nil Bound Total AMS. B Brazil is one of the exceptions. Applied support counting toward the limit is measured in an annual Current Total AMS (CTAMS). There are de minimis thresholds below which product-specific and non-product-specific AMS support can be exempted from counting in the CTAMS. These thresholds are 10 percent of value of production for Brazil and India (as developing countries), 8.5 percent for China (as negotiated during its accession), and 5 percent for the Russian Federation (as a developed country). For India and China, the de minimis thresholds are the effective limits on AMS support: an AMS that exceeds the threshold is counted in its entirety in CTAMS, which is not allowed to exceed these countries' nil Bound Total AMS. Three categories of support are exempt from the limits on AMS support. Support through measures that "have no, or at most minimal,

5 As an exporter of, for example, wheat, the Russian Federation's domestic support interests with respect to this commodity may differ not only from those of China, an increasing importer of wheat, and India, whose wheat imports have dwindled, but also from those of Brazil, whose wheat exports are growing while it remains a net importer. As an importer of meats, while also in the process of developing its own livestock industry, the Russian Federation's interests may diverge from those of meat-exporting Brazil. Kiselev and Romashkin (2012) discuss the Russian Federation's agricultural trade with developing countries.

6 Brink $(2009,2011)$ provides detailed and comprehensive descriptions.

7 Anderson $(2009,2012)$ shows that developing countries as a group from the 1950s on effectively taxed agriculture: the nominal rate of assistance was negative albeit rising. By the late 1990s the nominal rate of assistance for agriculture in developing countries as a group had turned positive, and it remained positive in 2000-2004 and 2005-2010. 
trade-distorting effects or effects on production" and that meet certain specific criteria is exempt as what is usually called Green Box support. Certain payments associated with production-limiting programs are exempt as Blue Box support. A third exempt category excludes, for developing countries only, general investment support for agriculture and input subsidies to low-income or resource-poor producers. It is sometimes called the Development Box.

The product-specific AMS includes price-related payments to producers, certain other types of product support and levies, and an indicator of market price support (MPS). The MPS is calculated "using the gap between a fixed external reference price [from the 1986-1988 base period] and the applied administered price multiplied by the quantity of production eligible to receive the applied administered price" (WTO 1995b). The WTO indicator of MPS differs from an economic measurement that uses the gap between contemporaneous domestic and world market prices and the total quantity of production to gauge the size of the transfer to producers resulting from policies that maintain that gap. ${ }^{8}$ The method for calculating WTO MPS is enshrined in the text of the Agreement on Agriculture and has not been considered for change in the Doha negotiations. Some countries, while following this method and also referring to policy changes concerning applied administrative prices and eligible quantities of production, have notified significantly reduced amounts of WTO MPS.

\section{BIC Agricultural Support and Support Notifications}

Agricultural policies among the BIC have differed in the type and level of support provided. ${ }^{9}$ In Brazil a distinction is drawn between commercial farmers and family farmers. Support is delivered primarily through credit programs (including debt rescheduling), directed to both commercial and

8 The use of administered prices in the WTO MPS results from designing it to account only for domestic measures, to the exclusion of border measures, such as tariffs. It was also designed as an indicator whose size could be entirely controlled through policy decisions, meeting some governments' concern about taking commitments on a variable outside their control. This led to the use of fixed reference prices and eligible production, as distinct from current reference prices and total production, which are beyond government control. Recognizing that the WTO MPS does not, despite its name, measure market price support in an economic sense, economic analysts exercise caution when introducing the WTO MPS in their work. The OECD, in contrast to the WTO, uses an economic measurement in the producer support estimate (PSE); see, for example, OECD (2012). The World Bank also uses an economic approach to examine agricultural protection and support since the mid-1950s (Anderson 2009).

9 This section draws from and updates the chapters by Nassar, Cheng, and Gopinath and the conclusion chapter by the editors in Orden, Blandford, and Josling (2011). 
family farmers. Price and income support programs for certain commodities—including edible beans, maize, wheat, rice, and soybeans—are oriented to commercial farmers. For India, self-sufficiency in production has been a goal of agricultural policy since independence. This has largely been achieved for staple grains but less so for pulses and vegetable oils. India maintains programs of administered prices (minimum support prices) for cereals, pulses, oilseeds, sugar, and cotton and makes extensive use of tariffs and tariff-rate quotas to protect its domestic agriculture. Its output price policies are administered countercyclically (at times of high world prices, India has lowered tariffs and imposed export restrictions to put downward pressure on domestic prices). India has provided substantial subsidies for inputs such as fertilizer, electricity, and irrigation.

In China various policies have discriminated against agriculture historically, for example, through agriculture-specific taxes or by maintaining commodity prices below market-determined levels. The discrimination against agriculture has been reversed and farmers are now supported through input subsidies, direct payments, and price support. China reports most of this support as AMS support, which, although increasing, is accommodated within the de minimis thresholds (some direct payments are reported as Green Box support). Investment in agriculture-related infrastructure projects is a large component of government budgetary support for agriculture.

Summaries of the BIC domestic support notifications are given in Figure 5.2 for 1995-2008. Brazil and India notify their support in US dollars, and China (from 1996) notifies in its own currency (the average 1996-2008 exchange rate was around 8 Chinese renminbi per US dollar). Since India's notifications were available only through 2003-2004 by October 2012, Gopinath's (2011) estimated (shadow) notifications are used for the years 2004-2005 through 2008-2009. Brazil is the only BIC that has a nonzero, though small, Bound Total AMS. Brazil notifies MPS and some other support (primarily certain credit subsidies and price support payments) as product-specific AMS. The AMS for one or more products (cotton or wheat) has exceeded the de minimis threshold in a few years in Brazil as shown in Figure 5.2a. Thus Brazil has used the policy space for specific crops that results from having a nonzero Bound Total AMS. The resulting sum of AMS support counted in Brazil's CTAMS has always been well below the Bound Total AMS. The small magnitude of Brazil's product-specific AMS support is given perspective in Figure 5.2b. The rightmost bar for each year shows 10 percent of the value of total agricultural production. Brazil's 
product-specific AMS support summed across all commodities is always less than 1 percent of total production value.

India's and China's product-specific AMS support has completely (India) or primarily (China) consisted of WTO MPS. The de minimis thresholds are effectively these countries' constraints on such support. The WTO MPS for India (calculated using reference prices and administered prices converted to US dollars) and China has been or is estimated to have been negative or zero for many years (Figure 5.2c and Figure 5.2d. This occurs when administered prices were below external reference prices for key food staples (rice and wheat) or no quantity was indicated as production eligible for the price support. ${ }^{10}$ Because of the methodological issues relating to prices and eligible production, the notified WTO MPS does not correspond to the economic market price support provided in either country. Farmers growing rice or wheat in India and China have been "disprotected" (effectively taxed) by output pricing policies in certain years since 1995 , but mostly they received positive economic market price support after 2000. Disprotection occurred again in India and China when world prices rose sharply in 2008 and policy interventions were used to insulate domestic markets from the increase.

Support under the other notified categories is also shown in Figure 5.2b, Figure 5.2c, and Figure 5.2d. No BIC has notified Blue Box support. Green Box support has increased quite regularly in nominal value and as a percentage of the total value of agricultural production in India and China, but it has fluctuated in Brazil. The level of Green Box support as a percentage of total production value, the explanation for growth in support, and the composition of the Green Box support (not broken down in Figure 5.2) differ among the three countries. ${ }^{11}$ Green Box support is nearly 10 percent of the total value of production in India and China, but for Brazil, Green Box support falls to its

10 The increases in administered prices in India since the last notified year (2003-2004) have raised them to significantly higher levels than the external reference prices in rupees. Gopinath's $(2011,2012)$ estimates of MPS closely match India's notifications for the years 1998/1999-2003/2004 and indicate a positive price gap in US dollars for rice and wheat from around 2008/2009. A US industry report (DTB Associates 2011) takes issue with the use of only actual procurement by the government as the eligible quantity rather than total production. As a commodity's administered price is being raised, using total production would make its AMS exceed the de minimis threshold at an earlier point in time than if only procurement were used.

11 Caution is appropriate in making cross-country comparisons of levels of support in the notifications. Each country exercises substantial discretion in the measures it notifies to the WTO and in the measurement of levels of support. Although scrutiny of the notifications occurs through the WTO Committee on Agriculture and through dispute proceedings, no systematic corroboration is undertaken to ensure comparability of the notified support. 

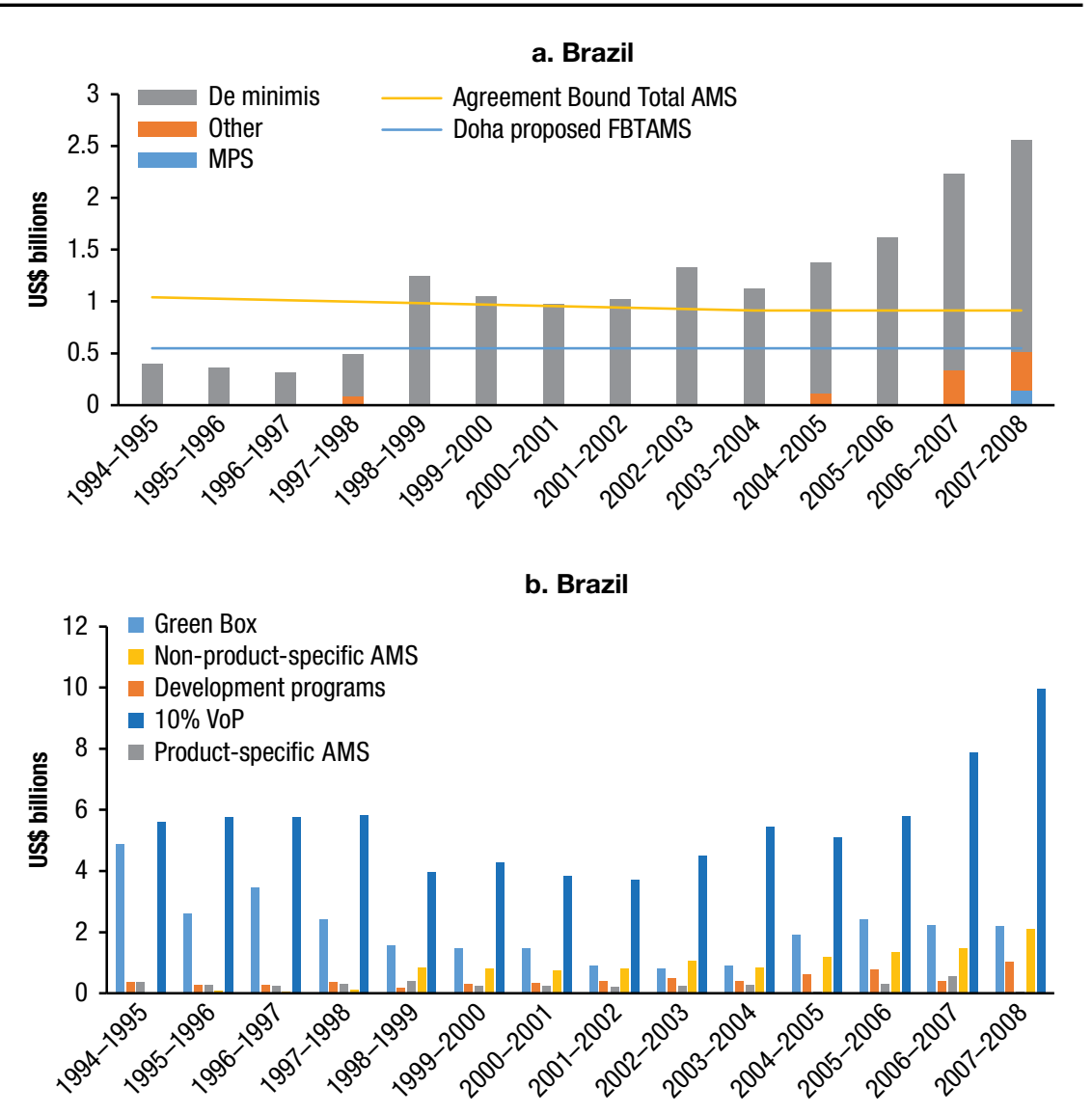

lowest value in 2002-2003, and remains only about 2-4 percent in later years. India's Green Box support is primarily composed of expenditures directed toward subsidizing low-income food consumers. If this public stockholding for food security is set aside, India's Green Box support is only about 2 percent of the total value of production in 2008-2009, less than in Brazil. China notified Green Box support of 593 billion renminbi in 2008 (US\$87 billion), a large component of which consists of infrastructure investments. Such investments are not included to the same extent in the notifications of the other countries. China's Green Box support also includes direct payments to grain 


\section{c. India}

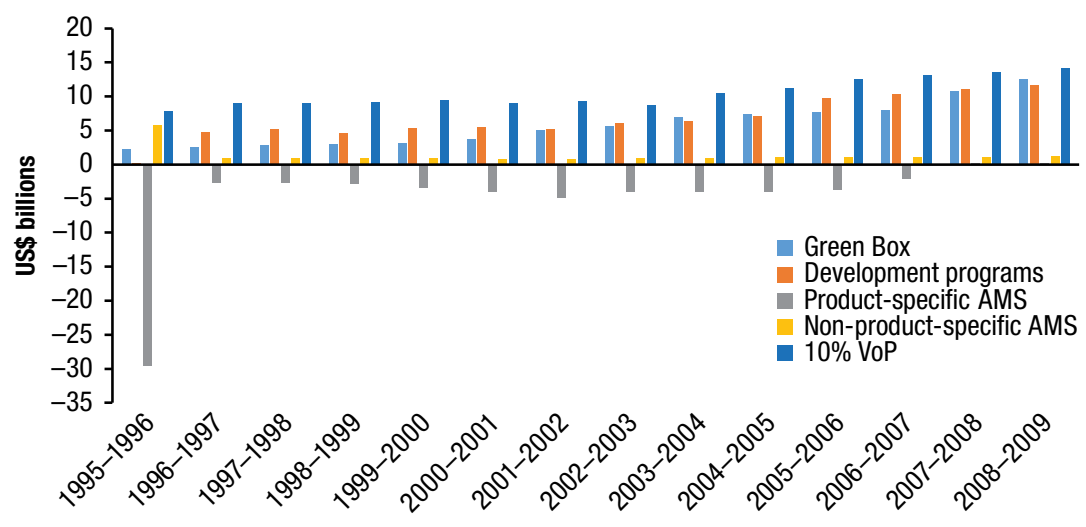

d. China

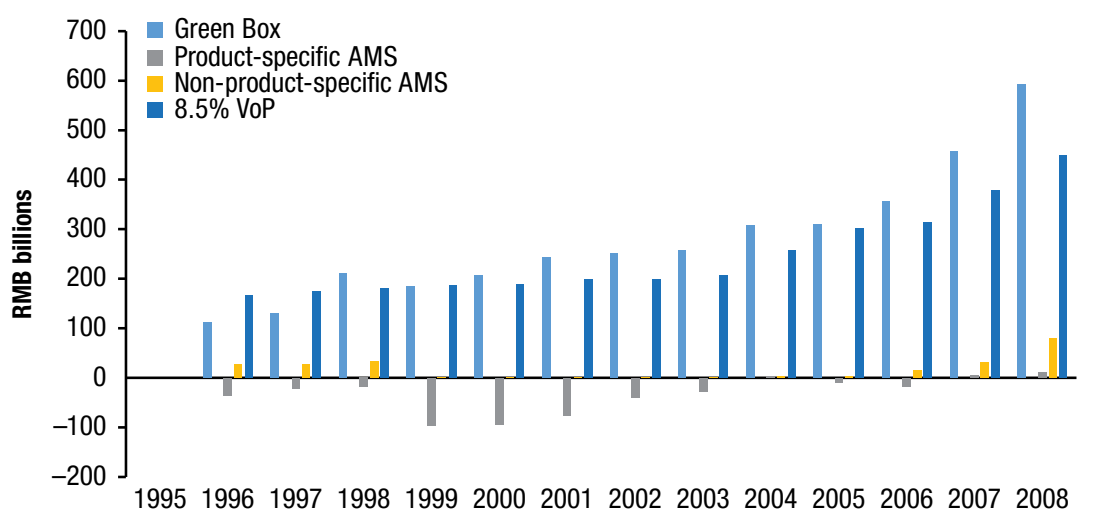

Source: Domestic support notifications submitted to the WTO Committee on Agriculture (series G/AG/N), various notifications by each country and estimated by Gopinath (2011).

Note: MPS = market price support; AMS = Aggregate Measurement of Support; FBTAMS = Final Bound Total AMS; VoP = value of protection.

producers notified as decoupled income support since 2004; these have been less than 1 percent of total agricultural production value. ${ }^{12}$

The BIC have notified various types of input and investment subsidies. India has notified this support primarily under the exemption for development programs. India's development program support averages a relatively high level of about 8 percent of the total value of production, in part because

12 Huang et al. (2011) argue that China's support policies have caused few distortions to grain acreages or input use. 
it notifies significant subsidies for electricity and irrigation. ${ }^{13}$ Brazil has notified smaller amounts of support under the development program exemption (averaging less than 1 percent of production value) and as non-product-specific AMS support: these values increase in later years due to investment credit subsidies and debt rescheduling. The level of China's non-product-specific AMS support, comprising mainly input subsidies, increased rapidly from 2006 but remained less than 1.5 percent of the value of production in 2008 , before increasing sharply (not shown) in later years. China has not notified subsidies for irrigation or electricity, a potentially important omission.

Overall, the BIC have notified less support than the developed countries, but the levels of support in India and China have increased over time both nominally and relative to total agricultural production value. Because of its fluctuating Green Box support, Brazil's notified support is seen to have increased only in the more recent years. The estimated total of all notified support for agriculture (including nonexempt and exempt support under the WTO rules) was of a similar order of magnitude relative to the total value of agricultural production in China and India as in the United States in 2008. ${ }^{14}$ This was a year of low US price-linked subsidies because world market prices for agricultural products were relatively high. With a porous international Agreement on Agriculture, domestic support policies remain heterogeneous across the BIC.

\section{Domestic Support Disciplines under the Russian Federation's WTO Accession}

The Russian Federation became a developed-country member of the WTO in August 2012 after the conclusion of an accession process that had been under

13 In its notifications for 1996-1997 and 1997-1998, 80 percent of India's notified subsidies for fertilizer, electricity, and irrigation were included in the development program category, based apparently on the share of small farms in the total number of farms (Gopinath 2011). Subsequently, in its notification made in 2011, India notified all such input subsidies from 1998-1999 through 2003-2004 under the development program exemption, noting that close to 100 percent of farm holdings are those of low-income, resource-poor farmers (WTO 2011b). Gopinath's shadow notification estimates in Figure 5.2c follow India's earlier notification practice and thus continue to divide the non-product-specific support between development programs and non-product-specific AMS using the 80 percent calculation. For the years 1998-1999 through 2003-2004, the sum of non-product-specific support Gopinath estimates under development programs and as AMS averages about US $\$ 1.4$ billion less than notified by India. See Gopinath (2012) for further discussion of India's 2011 notification.

14 In this calculation of total support, public stockholding for food security programs in India and domestic food aid in the United States are deducted from the notified Green Box support (see Orden, Blandford, and Josling 2011, Chapter 11). 
way from before the formation of the WTO in 1995. In the final stages of the accession negotiations, the size of the Russian Federation's Bound Total AMS became one of the contentious issues. One reason for this was the rising levels of agricultural support in the Russian Federation since around the year 2000, which made agricultural exporting countries concerned about potentially having to compete with heavily supported Russian producers both in the Russian Federation and in third-country markets. The increasing levels of support in the Russian Federation were documented in, for example, the policy monitoring carried out by the OECD, and they were also apparent in the base data provided by the Russian Federation over the years in line with the requirements of the WTO accession process. According to those requirements, the Russian Federation provided data for a rolling series of three-year periods in formats similar to those members use to notify their yearly support levels to the WTO Committee on Agriculture (WTO 1995a). ${ }^{15}$ Moreover, senior Russian Federation officials, including the minister of agriculture, repeatedly expressed the view that the Russian Federation's room to provide farm support should be of a certain size, even stating the desired large levels.

Support as measured by the OECD (but excluding market price support) declined from 1991-1993 to its lowest point in 1999-2001 (Table 5.1). From there it increased to US\$6.1 billion in 2008-2010, about the same level as in 1991-1993. The Russian Federation is reported to have originally submitted WTO domestic support data for 1991-1993 and proposed a Bound Total AMS of US\$16.2 billion (OECD 2007). Subsequently the Russian Federation provided data for 1993-1995 and proposed a Bound Total AMS of US\$9 billion (OECD 2007, 2009). This was followed by data for 2001-2003 and 2004-2006 (Ministry of Economic Development 2008). Eventually the idea of a Bound Total AMS starting at US $\$ 9$ billion and then declining to US $\$ 4.4$ billion a few years later was introduced in the negotiations (RIA Novosti 2010).

The Russian Federation's Bound Total AMS as agreed in its accession is US $\$ 9.0$ billion in 2012 and 2013, declining in equal steps to reach US $\$ 4.4$ billion in 2018 and then staying at that level. ${ }^{16}$ The data underlying

15 For acceding countries, a more recent base period than 1986-1988 is conventionally used for domestic support. For example, China's base period is 1996-1998.

16 In agriculture, the Russian Federation also has market access commitments and a nil export subsidy commitment. The final bound tariff in agriculture averages 10.8 percent, compared to an average applied tariff ranging between 13.2 percent and 14.6 percent in the years 2007-2011, and tariff-rate quotas apply to beef, pork, and pork trimmings (until 2020), some poultry products and some whey products (Kiselev and Romashkin 2012; WTO 2011d). 
TABLE 5.1 The Russian Federation's support for agriculture (OECD Producer Support Estimate excluding market price support) (US\$ billions)

\begin{tabular}{lccccccccc}
\hline & $\begin{array}{c}1991- \\
1993\end{array}$ & $\begin{array}{c}1992- \\
1994\end{array}$ & $\begin{array}{c}1993- \\
1995\end{array}$ & $\begin{array}{c}1994- \\
1996\end{array}$ & $\begin{array}{c}1995- \\
1997\end{array}$ & $\begin{array}{c}1996- \\
1998\end{array}$ & $\begin{array}{c}1997- \\
1999\end{array}$ & $\begin{array}{c}1998- \\
2000\end{array}$ & $\begin{array}{c}1999- \\
2001\end{array}$ \\
\hline $\begin{array}{l}\text { Three-year } \\
\text { average }\end{array}$ & $\mathbf{5 . 8}$ & 6.4 & $\mathbf{7 . 6}$ & 7.6 & 5.2 & 3.6 & 2.3 & 1.7 & 1.4 \\
\hline & $2000-$ & $2001-$ & $2002-$ & $2003-$ & $2004-$ & $2005-$ & $2006-$ & $2007-$ & $2008-$ \\
& 2002 & 2003 & 2004 & 2005 & 2006 & 2007 & 2008 & 2009 & 2010 \\
\hline $\begin{array}{l}\text { Three-year } \\
\text { average }\end{array}$ & 1.4 & 1.4 & 1.5 & 1.8 & $\mathbf{2 . 0}$ & 2.6 & $\mathbf{4 . 0}$ & 5.2 & 6.0 \\
\hline
\end{tabular}

Source: OECD (2011).

Note: The Russian Federation's representation of any WTO MPS (market price support) in its accession documents for most of these years does not appear to have been made public. The Organisation for Economic Co-operation and Development (OECD) MPS is calculated very differently from the WTO MPS. The OECD MPS is therefore simply subtracted from the PSE levels, generating essentially an indicator of budgetary support only. Averages are calculated from annual data, converted to US dollars using yearly exchange rates, in OECD (2011). Amounts in bold refer to years for which the Russian Federation is reported to have submitted data in line with WTO methodology.

the final value of the commitment refer to the 2006-2008 period. As shown in Table 5.2, the Russian Federation's AMS support increased significantly in 2008 over the 2006 and 2007 levels. It can be conjectured, based on the OECD data series, that a larger Bound Total AMS would have resulted if support data for 2007-2009 had been used to determine its level, since budgetary support in the OECD data was larger in 2009 than in 2006. As a developed country, the Russian Federation's de minimis percentage is 5 percent and it does not have access to the developing-country exemption for certain development programs. The Russian Federation expresses its commitment in US dollars. This gives the Russian Federation some protection against a drop in the value of its currency relative to the US dollar: having a nominal Bound Total AMS in a depreciating domestic currency reduces the real amount of distorting support the country can provide without violating its WTO obligation. ${ }^{17}$

The Russian Federation's accession commitments in domestic support are unusual because they start at a negotiated level higher than in its base period and then decline in five steps to the final bound level. Some other acceding members have taken reductions over a transition period, but the starting point has been an amount calculated from the data for the base period, not an

17 The Agreement and the WTO requirements (WTO 1995a, 1995b) are silent on what currency to use for the Total AMS commitment. Brazil's data underlying the commitment level are in US dollars only; India's and China's are in their own currencies. The Russian Federation expresses its underlying data in both roubles and US dollars, along with an exchange rate. This provides for greater transparency than if only US dollars were used. 
TABLE 5.2 Calculation of the Russian Federation's Current Total AMS in base years 2006-2008

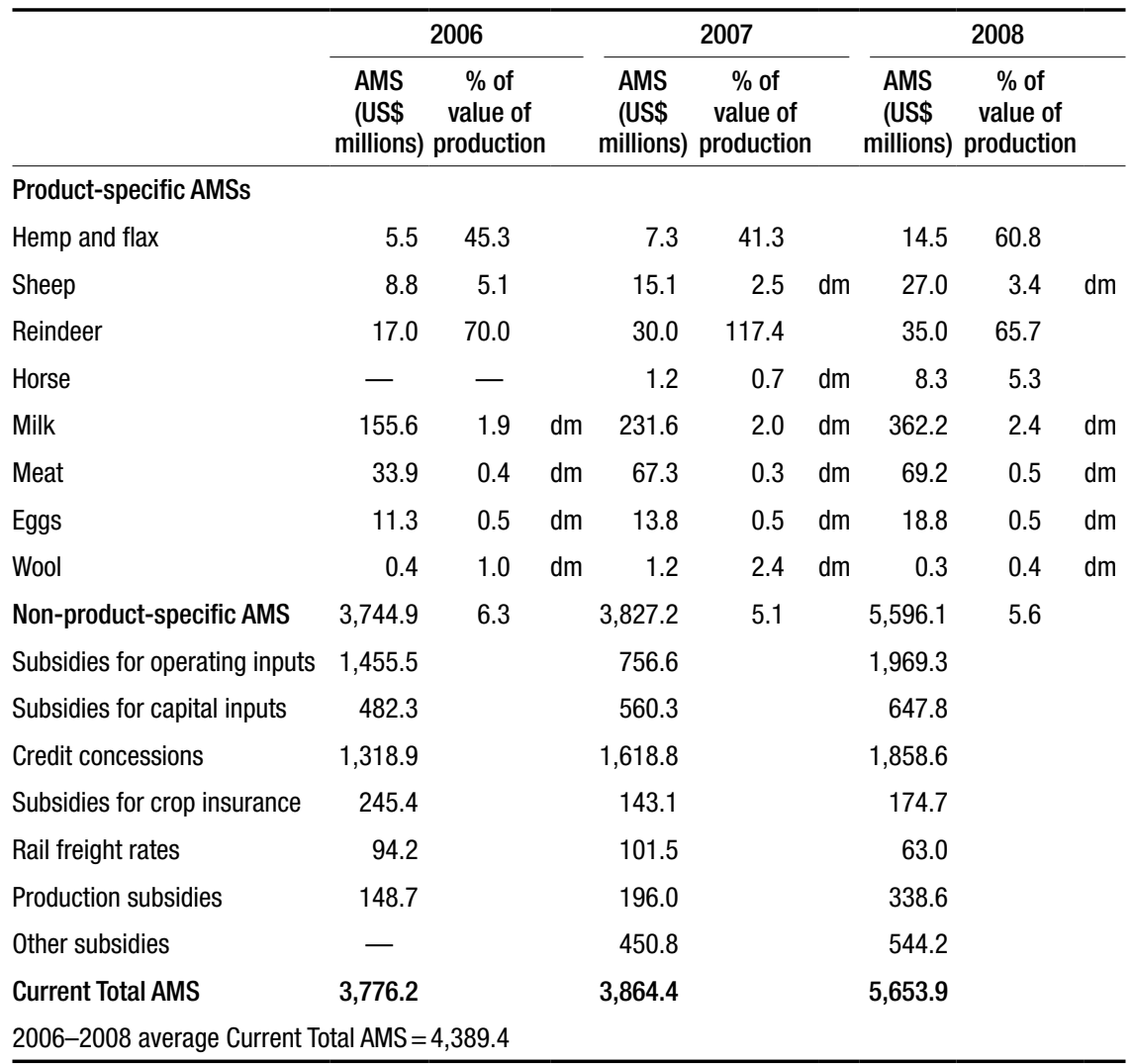

Source: WT0 (2012).

Note: $\mathrm{dm}=$ de minimis (no more than $5 \%$ of the product's or agriculture sector's value of production). $-=$ not reported. AMS = aggregate measurement of support.

Current Total AMS is the sum of all non-de minimis AMSs. Non-product-specific AMS subcategories are based on interpretation by Brink of 23 programs reported in the source document.

amount unrelated to past support in that period. ${ }^{18}$ In the Russian Federation's case, the US $\$ 4.4$ billion support level in the 2006-2008 period corresponds to the end point of the reductions, not the starting point. A unique and possibly significant element of the provisions that apply to the Russian Federation

18 The members who have taken such reductions include Croatia, Lithuania, the Republic of Moldova, and Taiwan; China, who reduced their commitments by the 20 percent used by developed countries in the Uruguay Round; and Jordan and Saudi Arabia, who reduced by the corresponding 13.3 percent for developing countries. Only Bulgaria, which reduced by 79 percent, is similar to the Russian Federation in the extent of reduction undertaken after accession (Brink [2003] discusses the Bulgaria case). 
is a rule regarding product-specific AMS support. Although applying only through 2017, it requires the sum of all product-specific AMS support to be no more than 30 percent of the non-product-specific AMS (WTO 2011c, paragraph 1187). This constraint on product-specific AMS support echoes the initiatives in the Doha negotiations to set product-specific limits. For the Russian Federation the rule prevents an early large shift from non-productspecific to product-specific AMS support.

According to the OECD, market price support makes up a large share of policy support to agricultural producers in the Russian Federation-some 65 percent of the producer support estimate (PSE) consists of market price support. The main instruments of price support are border measures, such as tariffs and nontariff measures, which do not enter the calculation of the WTO MPS. In the WTO base data for 2006-2008, the Russian Federation does not report any administered price larger than the fixed external reference price (FERP) and hence reports no market price support. Apart from other differences in policy coverage between PSE and AMS support, the 20062008 amounts calculated with the WTO methodology, and which correspond to the Russian Federation's final Bound Total AMS of US $\$ 4.4$ billion, are therefore significantly smaller than the support measured by the OECD PSEs for the Russian Federation in 2006-2008.

The Russian Federation's budgetary agricultural support is provided mainly through measures within multiyear frameworks. The support reported by the Russian Federation for 2006 and 2007 included support provided through programs under the 2006-2007 National Priority Project for Development of the Agro-Industrial Complex (OECD 2007). The 2008 support was delivered mainly through instruments under the State Program for Development of Agriculture 2008-2012. The support programs were very similar under the two frameworks. A large part of support, whether Green Box or AMS support, is provided by regional authorities. This is particularly the case for recent initiatives to modernize livestock production. The Russian Federation claimed significant amounts of support (average of US $\$ 2.1$ billion in 2006-2008) as eligible for the Green Box exemption. Most of this support was in the form of general services such as research, training, inspection, pest and disease control, and enhancement of soil fertility. Only very small amounts were claimed under the direct payment clauses of the Green Box.

As shown in Table 5.2, during the base years 2006-2008 product-specific AMS support, mainly for livestock products, was generally small enough to fall below the de minimis threshold, except in the very small production sectors of flax, hemp, reindeer, and horses. The non-product-specific AMS 
accounted for almost all of the Russian Federation's AMS support. It included subsidies for fertilizer, chemicals, fuel, feed, seed, machinery leasing, breeding animals, and crop insurance, as well as credit and other concessions. The dominance of non-product-specific AMS support is unusual among developed countries, although non-product-specific support does make up a large share of non-Green Box support in the BIC, as discussed above. As a developed country, the Russian Federation cannot exempt any of its non-product-specific support as development program support. If the Russian Federation had reported only slightly less support as non-product-specific AMS, it would not have exceeded the de minimis threshold (especially in 2007), and the resulting base-period CTAMS would have amounted to almost nothing, leading to a much smaller Bound Total AMS.

The Russian Federation's final Bound Total AMS of US\$4.4 billion is of some significance in relation to the size of the agriculture sector. It corresponds to 5.7 percent of the Russian Federation's 2006-2008 value of production of some US $\$ 78$ billion. However, the value of production has been increasing rapidly: US $\$ 59$ billion, US $\$ 76$ billion, and US $\$ 99$ billion in 2006 , 2007 , and 2008, respectively. Even in the very poor harvest year of 2010 the value of production remained around US $\$ 99$ billion (Federal State Statistics Service 2011), making the final Bound Total AMS correspond to around 4.5 percent of the 2010 value of production. By comparison, Brazil's Bound Total AMS of US $\$ 0.9$ billion was only 1.1 percent of its production value of US $\$ 82$ billion. On the other hand, the United States's Bound Total AMS of US $\$ 19.1$ billion was 6.7 percent of the 2009 notified value of production of US $\$ 285$ billion, and the EU27 Bound Total AMS of 72.2 billion euros was 21 percent of the 2008-2009 notified value of production of 344 billion euros. Although Russian Federation's 2013 Bound Total AMS (US\$9 billion) corresponds to 9 percent of the 2010 value of production, the relative size of the Russian Federation's final Bound Total AMS in 2018 would appear to be more constraining than is the case for the United States and the European Union. The contrast will become sharper if the value of production in Russian Federation agriculture continues to increase rapidly in the future. ${ }^{19}$

The Russian Federation could ease the constraint of its Bound Total AMS to some extent by introducing product-specific AMS support within the de minimis thresholds for each product, at least after the expiration in 2017 of its unique transition rule on such support. In the longer term it may also be possible for the Russian Federation to change the specifics of some of its

19 Liefert and Liefert (2012) discuss the potential for such a development to materialize. 
non-product-specific AMS programs in order to make the revised programs qualify for the Green Box exemption. Bringing non-product-specific AMS support below the de minimis threshold would free up room for additional product-specific AMS support above de minimis levels within the Russian Federation's Bound Total AMS.

These considerations begin to arise with the 2008-2012 State Program coming to an end. The Russian Federation's cabinet approved in July 2012 a new long-term plan to support agriculture in 2013-2020. Media reports indicate that subsidies for fuel and fertilizers would be terminated, while other subsidies would be introduced. The new subsidies would be paid per hectare of farm land and per liter of milk (Medetsky 2012). Details are scarce and it is not clear when legislation will pass. Without details it is not possible to judge in which category the Russian Federation might be able to place any future hectare-based support-AMS, Blue Box, or Green Box. However, if the Russian Federation were to report significantly less support as nonproduct-specific AMS, it would more easily stay below the Bound Total AMS as this limit declines from 2013 to 2018. The Russian Federation authorities have long emphasized a need to increase the production of livestock. If more support were put in place toward this goal, such as MPS relying on administered prices, some of it could be reported within the larger flexibility for product-specific AMS available after the expiration of the special rule in 2017. The presence of the Bound Total AMS means, however, that the Russian Federation's AMS support will be limited by international commitments, which was not the case before its WTO accession.

\section{Continued Support Latitude under the Doha Round Proposals}

One of the aims of the Doha agricultural negotiations is a substantial reduction in trade-distorting support. Strengthened and improved rules and commitments for domestic support were part of the framework agreed upon in 2004, but the negotiations stalled in December 2008. The Doha draft modalities (WTO 2008) remain indicative of both the tightening of the provisions governing trade-distorting domestic support that could (and perhaps eventually will) result from Doha and the space for future policies that countries are currently seeking to maintain. Bound ceiling levels on domestic support would be tightened and extended for certain countries under the Doha proposals. Doha would sharply reduce the Bound Total AMS, lower the de minimis percentages for a number of countries, and introduce a limit on overall 
Blue Box support. Doha would place a ceiling on a new indicator of overall trade-distorting support (OTDS), calculated as the sum of the CTAMS, de minimis AMS support, and overall payments in the Blue Box. The proposals would also impose product-specific limits on AMS support and Blue Box payments.

The Doha domestic support provisions would have a major impact on the levels allowed for some developed countries, but less so for the BRIC. The proposed final commitments of the BRIC (after phase-in periods over eight years) are shown in Table 5.3, with the proposed US final commitments (after phase-in over five years) given for comparison. The Doha proposals encompass a harmonizing approach, in which the countries that provided the largest support in the past would make the largest percentage cuts to their commitments. For the United States, the OTDS limit would decline from a base level of US $\$ 48.5$ billion to a Final Bound OTDS commitment of US $\$ 14.5$ billion, which corresponds to 7.4 percent of its base-period total production value. The existing US Bound Total AMS of US $\$ 19.1$ billion would drop to US $\$ 7.6$ billion. Further constraint would come from reducing the de minimis percentages for the United States and most other developed countries from 5 percent to 2.5 percent. Total Blue Box support would be limited to 2.5 percent of the 1995-2000 value of production.

The commitments for Brazil follow a pattern similar to those of the United States but the reductions reflect the more lenient treatment for developing countries. Brazil's OTDS limit would decline by 37 percent from its base to a final bound level of US $\$ 8.3$ billion. Its Bound Total AMS would be reduced by 30 percent and its de minimis thresholds by one-third. No reductions are required from Base OTDS or in the de minimis thresholds for India or China. Overall, Blue Box support would be capped at 5 percent of baseperiod production value for the BIC.

One consequence of the Doha proposals is that the Final Bound OTDS of India and China (at 25 percent of base-period total value of production) would be larger than that of the United States. The OTDS support that India and China could provide (on a dollar basis at 2009 exchange rates) would be nearly US $\$ 26$ billion and US $\$ 86$ billion, respectively. ${ }^{20}$ However, India and China face the constraint within this OTDS scope that each product-specific AMS be kept within its de minimis threshold. This allows less AMS support

20 Under proposals for recently acceded members (RAMs), China's, and possibly the Russian Federation's, allowed trade-distorting support could even exceed the OTDS limit as long as the excess consists only of de minimis support (see Brink 2011). 
TABLE 5.3 Proposed Doha commitments and de minimis percentages

\begin{tabular}{|c|c|c|c|c|c|c|}
\hline \multirow[b]{3}{*}{ Domestic support category } & \multirow{3}{*}{$\begin{array}{c}\begin{array}{c}\text { United } \\
\text { States }\end{array} \\
\text { US\$ } \\
\text { billions }\end{array}$} & \multirow{3}{*}{$\begin{array}{c}\text { Brazil } \\
\text { US\$ } \\
\text { billions }\end{array}$} & \multirow{3}{*}{ 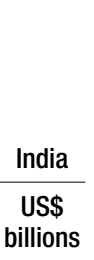 } & \multirow[b]{2}{*}{ China } & \multicolumn{2}{|c|}{ Russian Federation } \\
\hline & & & & & $\begin{array}{l}\text { If Recently } \\
\text { Acceded } \\
\text { Member } \\
\text { (RAM) }\end{array}$ & $\begin{array}{l}\text { If Very Recently } \\
\text { Acceded } \\
\text { Member } \\
\text { (VRAM) }\end{array}$ \\
\hline & & & & $\begin{array}{l}\text { RMB billion } \\
\text { (US\$ billions) }^{\mathrm{a}}\end{array}$ & $\begin{array}{l}\text { US\$ } \\
\text { billions }\end{array}$ & $\begin{array}{l}\text { US\$ } \\
\text { billions }\end{array}$ \\
\hline $\begin{array}{l}\text { Base Overall Trade-Distorting } \\
\text { Support (OTDS) }\end{array}$ & 48.5 & 13.1 & 25.6 & $\begin{array}{l}584.4 \\
(85.5)\end{array}$ & 10.2 & 10.2 \\
\hline $\begin{array}{l}\text { Full reduction percentage } \\
\text { from Base OTDS }\end{array}$ & 70 & 37 & - & - & 37 & - \\
\hline Final Bound OTDS & 14.5 & 8.3 & 25.6 & $\begin{array}{l}584.4 \\
(85.5)\end{array}$ & 6.5 & 10.2 \\
\hline Pre-Doha Bound Total AMS & 19.1 & 0.9 & - & - & 4.4 & 4.4 \\
\hline $\begin{array}{l}\text { Full reduction percentage } \\
\text { from pre-Doha level }\end{array}$ & 60 & 30 & - & - & 30 & - \\
\hline $\begin{array}{l}\text { Final Bound Total AMS after } \\
\text { reduction }\end{array}$ & 7.6 & 0.6 & - & - & 3.1 & 4.4 \\
\hline Overall Blue Box limit & 4.9 & 2.4 & 5.1 & $\begin{array}{l}116.9 \\
(17.1)\end{array}$ & 1.9 & 1.9 \\
\hline \multirow[t]{2}{*}{ De minimis percentage } & 2.5 & 6.7 & 10.0 & 8.5 & 4.2 & 5.0 \\
\hline & \multicolumn{6}{|c|}{ Commitment as share of base-period value of production } \\
\hline Final Bound OTDS & 7.4 & 17.0 & 25.0 & 25.0 & 16.8 & 26.4 \\
\hline Final Bound Total AMS & 3.9 & 1.3 & - & - & 8.0 & 11.4 \\
\hline Overall Blue Box limit & 2.5 & 5.0 & 5.0 & 5.0 & 5.0 & 5.0 \\
\hline
\end{tabular}

Source: Authors' calculations for the Russian Federation; see Orden, Blandford, and Josling (2011) for the other countries. Note: 'Based on 2009 IMF average yearly exchange rates; "base period for OTDS is 1995-2000 for the United States and the Russian Federation (the Russian Federation's value of production was larger in 1995-2000 than in 1995-2004) and 1995-2004 for Brazil, India, and China. — = zero.

for each product relative to production value than some developed countries (and Brazil and the Russian Federation among the BRIC) have provided in the past for certain products. The Russian Federation's provision of productspecific AMS support within its OTDS scope might also be constrained. This would result from the product-specific AMS limits being based only on some earlier years' de minimis thresholds, expressed in monetary terms, in the absence of large product-specific AMS support in earlier years.

The Doha draft modalities of 2008 introduced different provisions for recently acceded members (RAMs) and very recently acceded members (VRAMs). It is commonly assumed that all those that have acceded under the WTO accession rules since 1995 (some 30 countries, including China) 
are recently acceded members. The draft modalities identify four VRAMs by name, but that list naturally goes only up to $2008 .{ }^{21}$ It is thus not clear whether RAM or VRAM provisions would apply to the Russian Federation under a continuation of Doha. As a WTO member, the Russian Federation is now in a position where it can influence that identification. Because a developed-country VRAM (such as Ukraine) would enjoy greater flexibilities than a developed-country RAM (such as Taiwan, China), the Russian Federation would be expected to argue for VRAM status. As a RAM, the Russian Federation would take a 37 percent reduction from its Base OTDS, while as a VRAM, it would not reduce from Base (Table 5.3). As a RAM, it would reduce its Bound Total AMS by 30 percent to US $\$ 3.1$ billion, while as a VRAM, it would not reduce. Likewise, as a RAM, it would reduce the de minimis percentage to 4.2 percent, but as a VRAM, it would keep it at 5 percent. Thus, if the Russian Federation were to be treated as a VRAM, Doha would not impose any reductions on the domestic support constraints the Russian Federation negotiated when acceding to the WTO, and some of the Russian Federation's new limits under Doha (such as overall Blue Box) would be set as for developing countries. ${ }^{22}$

\section{Conclusion}

This chapter has examined BRIC agriculture policies through the lens of the WTO's rules and ceiling commitments on domestic support. The BRIC have emerged collectively as a key set of players in the global economy, but their interests are not always convergent. The agricultural interests differ among the BRIC and the stance toward the WTO governance of agriculture policy differs among its members (Brazil, the Russian Federation, India, and China). As incomes have increased in India and China, agriculture support seems to be growing. The BIC domestic support notifications reflect increasing levels of support to an extent, but support as notified under the WTO rules can differ significantly from support measured in standard economic terms. The MPS as measured by the WTO may turn positive for India and China if administered

21 The four named VRAM countries are Saudi Arabia, the former Yugoslav Republic of Macedonia, Viet Nam, and Ukraine (WTO 2008). It is not clear whether VRAM is a subset of RAM or they are mutually exclusive categories.

22 The Russian Federation's overall Blue Box limit, whether a RAM or a VRAM, would be twice as large as it would have been if the Russian Federation were not recently acceded. If Doha provisions were to apply as soon as in the next few years, which is unlikely, the Russian Federation's ongoing reduction of the Bound Total AMS until 2018 would need to be considered when starting the implementation of any Doha reductions over time. 
prices are raised. The difference between using government procurement or total production as eligible production (which would hinge on specific policy details concerning the applied administered price) could then prove important in determining the scope these countries have for providing support while remaining in compliance with the WTO rules and commitments. In addition, for India and Brazil the development program exemption could prove important for future compliance with support limitations. The Russian Federation's ceiling commitment upon accession in 2012 declines through 2018, albeit from a high level, and a special rule applies to product-specific support in the short run. This accommodates the non-product-specific policy emphasis in the Russian Federation's past support. In the longer run, should it choose to do so, the Russian Federation will be able to provide sizeable non-product-specific AMS support within the relevant de minimis threshold while also increasing product-specific AMS support beyond the de minimis thresholds for many products-a pattern of support seen in some other developed countries.

With the Russian Federation as a member, the BRIC divides into two groups in terms of constraints on product-specific AMS support under the WTO disciplines. In one group are Brazil and the Russian Federation. Despite their very different agricultural trade positions, both these countries have an established Bound Total AMS commitment under the WTO rules, which gives them some latitude in offering support for certain products. Brazil would, and the Russian Federation might, also face tighter constraints under the proposed Doha rules. India and China, in contrast, lack the latitude for product-specific AMS support that a nonzero Bound Total AMS commitment offers. Both they and possibly the Russian Federation would experience a milder tightening of the constraints on trade-distorting support than would Brazil under a Doha agreement. This contrast illustrates a more general point. Agriculture is likely to remain a component of the BRIC economies for which evaluating differences among the individual countries will remain at least as important as thinking of them collectively as a rising force in the world economy.

\section{Bibliography}

Anderson, K., ed. 2009. Distortions to Agricultural Incentives: A Global Perspective 1955-2007.

London: Palgrave Macmillan; Washington, DC: World Bank.

—. 2012. "Agricultural Price Distortions: Trends and Volatility, Past and Prospective."

Plenary paper, International Conference of Agricultural Economists, Foz do Iguaçu, Brazil, August 18-24. 
Brink, L. 2003. "New Members of the WTO: Their Commitments in Agriculture and Provisions Proposed in the Doha Negotiations." Paper presented at the Conference on Agricultural Policy Reform and the WTO: Where Are We Heading? Capri, Italy, June 23-26. Accessed September 2012. www.ecostat.unical.it/2003agtradeconf/Contributed\%20papers/brink.pdf. - 2009. "WTO Constraints on Domestic Support in Agriculture: Past and Future." Canadian Journal of Agricultural Economics 57: 1-21.

_. 2011. "The WTO Disciplines on Domestic Support." In WTO Disciplines on Agricultural Support, edited by D. Orden, D. Blandford, and T. Josling, 23-58. Cambridge, UK: Cambridge University Press.

Cheng, F. 2011. “China." In WTO Disciplines on Agricultural Support, edited by D. Orden, D. Blandford, and T. Josling, 310-352. Cambridge, UK: Cambridge University Press.

DTB Associates. 2011. "Domestic Support and WTO Obligations in Key Developing Countries." Unpublished, DTB Associates, Washington, DC.

Federal State Statistics Service. 2011. "Agricultural Production Output by Type of Agricultural Farms." Accessed August 2011. www.gks.ru/bgd/regl/b11_12/IssWWW.exe/stg/d01/15-01 .htm.

Gopinath, M. 2011. "India." In WTO Disciplines on Agricultural Support, edited by D. Orden, D. Blandford, and T. Josling, 277-309. Cambridge, UK: Cambridge University Press.

— 2012. "WTO Disciplines on Agricultural Support Update: A Comparison of India's WTO Domestic Support Notifications with Shadow Measurements.” WTO Domestic Support Notification Update. Unpublished, Oregon State University, Corvallis, OR, US. Accessed September 2012. http://ebrary.ifpri.org/cdm/ref/collection/p15738coll5/id/3566.

Huang, J., X. Wang, H. Zhi, Z. Huang, and S. Rozelle. 2011. “Subsidies and Distortions in China's Agriculture: Evidence from Producer-Level Data." Australian Journal of Agricultural and Resource Economics 55: 53-71.

Kerr, W. 2012. “Taming the Bear: The WTO after the Accession of Russia.” The Estey Centre Journal of International Law and Trade Policy 13: 150-159.

Kiselev, S., and R. Romashkin. 2012. Possible Effects of Russia's WTO Accession on Agricultural Trade and Production. ICTSD Issue Paper 40. Geneva: International Centre for Trade and Sustainable Development (ICTSD).

Lamy, P. 2011. “Director-General's Statement on Russia’s Accession.” World Trade Organization (WTO), December 16. Accessed September 2012. www.wto.org/english/news_e/sppl_e/ sppl213_e.htm.

Liefert, W. M., and O. Liefert. 2012. "Russian Agriculture during Transition: Performance, Global Impact, and Outlook." Applied Economic Perspectives and Policy 34: 37-75. 
Medetsky, A. 2012. “Cabinet Tweaking Agricultural Subsidies under WTO.” Moscow Times, July 15. Accessed September 2012. www.themoscowtimes.com/business/article/cabinet-tweaking -agricultural-subsidies-under-wto/462109.html.

Ministry of Economic Development. 2008. "On the Current State of Russia's WTO Accession Negotiations." December, World Trade Organization, Geneva.

Nassar, A. 2011. "Brazil." In WTO Disciplines on Agricultural Support, edited by D. Orden, D. Blandford, and T. Josling, 223-276. Cambridge, UK: Cambridge University Press.

OECD (Organisation for Economic Co-operation and Development). 2007. Agricultural Policies in Non-OECD Countries-Monitoring and Evaluation 2007. Paris: OECD.

- 2009. Agricultural Policies in Emerging Economies 2009-Monitoring and Evaluation. Paris: OECD.

— 2011. Producer and Consumer Support Estimates database. Accessed September 2012. www.oecd.org/tad/agricultural-policies/producerandconsumersupportestimatesdatabase .htm.

- 2012. Agricultural Policy Monitoring and Evaluation 2012: OECD Countries. Paris: OECD.

Orden, D., D. Blandford, and T. Josling, eds. 2011. WTO Disciplines on Agricultural Support: Seeking a Fair Basis for Trade. Cambridge, UK: Cambridge University Press.

RIA Novosti. 2010. "Russian Agricultural Minister Boosts WTO Accession—Paper." September 28. Accessed September 2012. http://en.rian.ru/business/20100928/160749576.html.

USDA (US Department of Agriculture). 2011. "Agricultural Exchange Rate Data Set, Nominal Annual Country Exchange Rates.” Accessed September 2012. http://ers.usda.gov/Data/ ExchangeRates/.

WTO (World Trade Organization). 1995a. "Accession to the World Trade OrganizationInformation to Be Provided on Domestic Support and Subsidies in Agriculture." WT/ACC/4, WTO, Geneva.

_. 1995b. Results of the Uruguay Round of Multilateral Trade Negotiations-The Legal Texts. Geneva: WTO.

—. 2008. "Revised Draft Modalities for Agriculture.” TN/AG/W/4/Rev.4, WTO, Geneva.

_.2011a. "Groups in the Agriculture Negotiations." Accessed September 2012. www.wto .org/english/tratop_e/agric_e/negoti_groups_e.htm. . 2011b. "Notification of Domestic Support, India." G/AG/N/IND/7, June 9. WTO, Geneva. 
- 2011c. "Report of the Working Party on the Accession of the Russian Federation to the World Trade Organization." WT/ACC/RUS/70; WT/MIN(11)/2, WTO, Geneva.

_. 2011d. "Working Party Seals the Deal on Russia's Membership Negotiations." Accessed September 2012. www.wto.org/english/news_e/news11_e/acc_rus_10nov11_e.htm.

-2012. Domestic Support and Export Subsidies in the Agricultural Sector. WT/ACC/ SPEC/RUS/39, August 23. WTO, Geneva. 
